\title{
Interpretacje
}

\section{Laboratorium artystyczne: realizm afektywny. Praktyki Joanny Rajkowskiej}

Agnieszka Dauksza

TEKSTY DRUGIE 2017, NR 1, S. 373-381

DOI: $10.18318 /$ td.2017.1.29

$\mathbf{T}$ radycyjnie pojmowany realizm, realizm „wielki” lub „bezprzymiotnikowy”, wydaje się dziś kategorią albo staroświecką, albo niejasną, nadto ogólną i nieadekwatną do współczesnego wyobrażenia realiów. Bardziej obiecujące wydają się próby jawnego zakorzenienia jej w konkretnym kontekście metodologicznym, historycznym i politycznym. W konsekwencji inwencyjnych prób opisu możemy dziś mówić m.in. o realizmie traumatycznym i historycznym, cielesnym, etnograficznym czy realizmie świadectwa. Odnosząc się do tych badań oraz do bardziej tradycyjnych definicji pojęcia, stawiam pytanie, jak na nowo problematyzować realizm jako operacyjną i przydatną poznawczo kategorię? Z pewnością koncepcja nowego realizmu musi wynikać ze specyfiki artystycznych realizacji przełomu XX i XXI wieku, najnowszej kultury „intensywności” i współczesnej wrażliwości artystycznej. Konieczne jest zaproponowanie języka, który obejmowałby co najmniej trzy aspekty: sprawcze aktanty, czyli twórcę, dzieło i odbiorcę, odczuwanie i doświadczanie rzeczywistości, wyobrażenie o formach reprezentacji tego doświadczenia, konstelację istniejących odniesień
Tekst powstał w ramach grantu finansowego ze środków Narodowego Centrum Nauki przyznanych na podstawie decyzji numer DEC-2013/11/N/ $\mathrm{HS}_{2} / 03509$.
Agnieszka Dauksza

- doktorantka w Katedrze Antropologii Literatury i Badań Kulturowych WP UJ. Autorka książek: Klub Auschwitz i inne kluby. Rwane opowieści przeżywców (2016) i Kobiety na drodze. Doświadczenie przestrzeni publicznej w literaturze przełomu XIX iXX wieku (2013). Obecnie przygotowuje książkę poświęconą afektom w literaturze modernizmu. Kontakt: agnieszka. dauksza@gmail.com 
kulturowych oraz szerszy kontekst historyczny. Jak łatwo zauważyć, tak rozumiany realizm nie może być rozpatrywany czysto teoretycznie, a powstające mikroteorie powinny wynikać z analiz konkretnego materiału.

Przyjmuję za punkt odniesienia praktyki artystyczne Joanny Rajkowskiej, gdyż intuicja badawcza podpowiada mi, że refleksja nad trybem ich oddziaływania może być pożyteczna nie tylko dla opisu sztuki Rajkowskiej, ale też - w dalszej perspektywie - może otwierać pole dla konstytuowania kategorii realizmu adekwatnego do współczesnej kultury.

Jedną z właściwości działań Rajkowskiej jest ich nieparafrazowalność wynikająca zapewne z czynnościowej dynamiki, wielotorowości wydarzania się, wreszcie, rozpiętego w czasie i przestrzeni przyciągania czy zagarniania rzekomo postronnych obiektów lub postaci. Wyrazistym tego przykładem jest choćby najlepiej rozpoznawane przedsięwzięcie artystki - Pozdrowienia zAlei Jerozolimskich. Trudno byłoby upierać się, że sedno ingerencji artystycznej sprowadza się do ustawienia sztucznej palmy pośrodku jednej z głównych ulic Warszawy. Owszem, palma w centrum stolicy to swoisty „kij w oko”, materialny trzon konceptu Rajkowskiej, ale o sile jego oddziaływania decyduje wieloaktowy spektakl wydarzeń rozgrywających się wokół obiektu: długotrwałych przygotowań do realizacji, sporów z lokalnymi władzami, procesów administracyjno-urzędowych, polemik, manifestacji i oddolnych inicjatyw (z jednej stronny potępiających, a z drugiej chroniących palmę - z Komitetem Obrony Palmy na czele), licznych użyć i nadużyć wizerunku palmy w mediach, a wreszcie funkcjonowania palmy wśród użytkowników warszawskiej przestrzeni publicznej'. Palma niekiedy pobudzała imaginarium marzących o awansie społecznym, kojarzyła się z wakacjami, relaksem, dobrobytem, kiedy indziej przeciwnie - wzbudzała niechęć czy agresję, przywodziła na myśl obcość kulturową, symboliczną różnicę, żydowskość lub arabskośćn.

Co charakterystyczne, jest to stała prawidłowość strategii artystycznej Rajkowskiej - o podobnym efekcie można mówić w przypadku Dotleniacza, Camping Jenin, Urodzonej w Berlinie czy Minaretu. Efektów jej pracy prawie nigdy nie można określić mianem dzieł. Jest to raczej dzianie się, konceptualna "czynnościowość”, w której obręb, niczym w sieć, zagarniane są zarówno procesy powstawania i realizacji, jak i recepcja oraz jej skutki. Artur Żmijewski

1 Niby, żeby, jest. Pozdrowienia z Alej Jerozolimskich, w: Rajkowska. Przewodnik Krytyki Politycznej, Wydawnictwo Krytyki Politycznej, Warszawa 2010, s. 25-61.

2 Tamże. 
stwierdza, że Rajkowska jest ,jedną z tych osób, które nazwano mylnie artystkami - z braku nazwy na ich działania i z braku innego miejsca"s. Faktycznie, można mówić o pewnym stuporze klasyfikacyjnym. Aktywność Rajkowskiej bywa najczęściej określana mianem sztuki publicznej, jednak także ta etykieta z wielu względów jest nietrafiona czy niewystarczająca. Chciałabym zaproponować inną perspektywę odczytania i rozpatrywać działania w kontekście koncepcji Theodora Adorna, co z kolei doprowadzi mnie do kategorii realizmu afektywnego.

Rajkowska przyznaje, że podstawa jej pracy to rejestrowanie napięć, wyczuwanie danych przestrzeni, jednostek i wspólnot. Mówi o sobie, że jest „sejsmografem”, który „tropi powiązania między ludźmi, zerwane albo kiełkujące relacje, namiętności, potrzeby i zaniechania", a robi to nie po to, by je zrozumieć, ale by „pozwolić sobie na pozaracjonalną reakcję na owe wrażenia"4. Ewidentnie właśnie z tych pozaracjonalnych rekcji rodzą się konkretne projekty Rajkowskiej - np. Dotleniacz miał być niemal chirurgicznym "nacięciem" chorej i skażonej tkanki dawnego obszaru warszawskiego getta, a pomysł na Minaret zrodził się z powidokowego przywidzenia, gdy artystka po powrocie z podróży na Bliski Wschód zobaczyła minaret w miejscu łódzkiego komina fabrycznego. Jak widać, zwykle artystka skupia się na konkretnym punkcie czy, jak to określa - miejscu bolesnym - i z tego właśnie punktu zaczyna projektować i rozpościerać konstelacyjną strukturę, sieć, w obręb której dostają się i w której zaczynają rezonować kolejne zjawiska.

W istocie działania artystki mają tę zdolność, o której pisał Adorno w Minima moralia: „sztuka pozostaje do tego, co jest w niej inne, w takim stosunku, jak magnes do pola żelaznych opiłków"', a dobrze skonstruowane dzieła: "wciągają wszystko, co krąży w okolicy" i nie tyle przedstawiająco odnoszą się do doświadczanej rzeczywistości, ile ją współtworzą, wywołują, eksponują i nadają jej jednostkową formę. W przypadku Rajkowskiej działania artystyczne są medium i narzędziem poznania, nie naśladują i nie odgrywają

3 Sztuka publicznej możliwości. Z Joanną Rajkowską rozmawia Artur Żmijewski, w: Rajkowska. Przewodnik Krytyki Politycznej, s. 241.

4 Tamże, s. 238.

5 T.W. Adorno Teoria estetyczna, przeł. K. Krzemieniowa, PWN, Warszawa 1994, S. 15.

6 T.W. Adorno Minima moralia. Refleksje z poharatanego życia, przeł. M. Łukasiewicz, Wydawnictwo Literackie, Kraków 1999, s. 97. 
rzeczywistości, lecz ją ewokują - dostępna poznaniu realność wydarza się i objawia właśnie w sieci relacji tej sztuki.

Ryszard Nycz, komentując pajęczo-sieciową koncepcję tekstu Adorna, zauważa, że bynajmniej

nie chodzi tu o zamkniętą strukturę wytwarzającą i przechowującą immanentne znaczenie w izolacji od środowiska zewnętrznego, lecz o sieć utkaną ze znaczących, wchodzącą w aktywne relacje z otoczeniem, w której formują się i profilują swą postać tyleż przedmioty, co ich poznanie.?

U Rajkowskiej na te sieciowe układy składają się zarówno elementy fizyczne, materialne obiekty, żywe jednostki, jak i konkretne przestrzenie - zarówno topograficzne, jak i mentalne. Artystka deklaruje, że wskutek perypetii rodzinnych i problemów zdrowotnych od najwcześniejszego dzieciństwa ćwiczyła „zwierzęcy instynkt” reagowania na własne i cudze niepokoje, pobudzenia i zaburzenia ${ }^{8}$. Rajkowska, porównując swoją praktykę do aktywności sejsmografu, skupia się na lokowaniu działań w „przestrzeniach naznaczonych” lub w „miejscach martwych”. Jednocześnie inicjuje i ustanawia nowe przepływy energetyczne - pozwala samej sobie twórczo reagować na afektywne intensywności, konfrontuje racje nietożsamych grup, prowokuje lokalne wspólnoty, obnaża niekonsekwencje władz, ingeruje w najczulsze tkanki miast. Można myśleć o generowanych relacjach jako „polach intensywności” czy „polach wzmożonej grawitacji”"10, jednak z różnych względów intryguje mnie zwłaszcza określenie tej sztuki mianem poligonu. Nie ulega bowiem wątpliwości, że Rajkowska - jak sama deklaruje - „wszystko włącza w obręb swojej pracy”, „pasożytuje na własnym życiu”"11, ale też bez obiekcji kusi, prowokuje i angażuje postronne jednostki do swoich celów. W rezultacie czyni poligon nie tylko z własnego ciała, lecz również z cudzych ciał, biografii, reakcji, zachowań, wrażliwości itd. Poprzez sztukę pasożytnictwa próbuje

7 R. Nycz Poetyka doświadczenia. Teoria-nowoczesność - literatura, Wydawnictwo IBL PAN, Warszawa 2012, s. 61.

8 Sztuka publicznej możliwości, s. 156.

9 J. Rajkowska Urodzona w Berlinie, http://www.rajkowska.com/pl/filmy/284 (14.06.16).

10 Sztuka publicznej możliwości, s. 157.

11 Zostało we mnie martwe pole. Joanna Rajkowska rozmawia z Aurelią Nowak, "Magazyn sztuki" $2012 \mathrm{nr} 3$. 
„poruszyć percepcję innych, uruchomić w nich proces pojawiania się różnego rodzaju pamięci i obrazów"12.

Co prawda Rajkowska odżegnuje się od porównań jej sztuki z pracą laboratoryjną, jednak mam wrażenie, że ma wówczas na myśli tradycyjne laboratoria. Za takie uważa wszelkie „zamknięte pudełka”, jak teatry czy galerie, które oskarża o sztuczne preparowanie idealnych warunków ${ }^{13}$. Tymczasem działania artystki są raczej "funkcjonalnym ekwiwalentem laboratorium" w rozumieniu, które proponuje Bruno Latour ${ }^{14}$. Praktykowanie sztuki przyjmuje postać prób i eksperymentów zmierzających do demonstrowania podziałów oraz uwidaczniania różnicy. Podobnie jak w przypadku Latourowskich rozważań na temat pracowni Pasteura, tu także granice laboratoryjnej przestrzeni okazują się przepuszczalne, zanegowana zostaje dychotomia wewnętrznego i zewnętrznego, trudno oddzielić porządek publiczny od intymnego, tracą na ostrości tradycyjne role. Artystka partycypuje w wydarzaniu się projektów na równych prawach z odbiorcami nadającymi dynamikę zdarzeń. Jak twierdzi Latour, w społeczeństwie-sieci: „laboratoria są stworzone po to, by naruszać bądź demontować samo rozróżnienie między wnętrzem i zewnętrzem, jak również pomiędzy skalą mikro a makro"15, oraz po to, by czynić zjawiska widzialnymi, naocznymi i oswajalnymi.

W przypadku Rajkowskiej wbrew pozorom nie chodzi wyłącznie o krytyczną refleksję nad wspólnymi, lecz nietożsamymi narracjami przeszłości i o obecne powidoki minionego. Ważne są także „przedwidoki” czegoś, co dopiero może się wydarzyć: „Przyszłość może tak samo boleć i cieszyć jak przeszłość. Ludzie przeczuwają, co może się wydarzyć. [...] to jest podwójnie ekscytujące: to coś dopiero, być może, stanie się realnością"16.

Nie bez kozery Rajkowska stwierdza wielokrotnie, że nie tyle chce wiedzieć, jak jest, ile „jak mogłoby być"17. Wiąże się to ze specyficznym pojmowaniem rzeczywistości, która funkcjonuje nie jako uprzedni, niezależny byt,

12 Rzeczywistość jestzawsze trochę dalej.Z Joanna Rajkowską rozmawia lga Gańczarczyk „Didaskalia" 2011 nr 102, s. 11.

13 Tamże, s. 13.

B. Latour Dajcie mi laboratorium a poruszę świat, przeł. K. Abriszewski, Ł. Afeltowicz, „Teksty Drugie" 2009, nr1-2.

15 Tamże, s. 165.

16 Rzeczywistość jest zawsze trochę dalej, s. 11.

17 Dotleniacz, w: Rajkowska. Przewodnik Krytyki Politycznej, s. 72. 
ale jako zdarzeniowość odciskająca swój ślad na ludzkim doświadczeniu, także artystycznym. Proponowany przez Rajkowską praktyczny sposób uwidaczniania ścisłego splotu tych porządków zastanawiająco rezonuje z myślą Adorna przekonującego, że „sztuka nie jest ani odbiciem, ani poznaniem czegoś przedmiotowego. Sztuka raczej wykonuje gest sięgnięcia po rzeczywistość, aby dotknąwszy jej, cofnąć się konwulsyjnie"18.

Właściwymi tematami projektów Rajkowskiej są próby mierzenia się z otaczającymi realiami. Jej sztuka prowokuje, doprowadza do konfrontacji, ale nie prowadzi do zmiany. Artystka pozostaje nieufna wobec medium języka, jest przekonana o niemożności rozwiązania konfliktów, które w istocie inspirują ją do działania. Z pieczołowitością rejestruje kolejne niepowodzenia komunikacyjne, kataloguje nieudane i niezrealizowane projekty, przyznaje się do bezradności. Utrzymuje jednocześnie, że w słabości i nie-sprawczości tkwi pewien potencjał. Joanna Jopek analizuje te "porażki” jako celowe sprzeniewierzenie się idei sensotwórczej produktywności, strategię znaczącego uniku, negatywną performatykę, która może mieć polityczne znaczenie ${ }^{19}$. Zgadzając się z jej rozpoznaniami, dostrzegam jednak pewną słabość tej koncepcji wynikającą zapewne z pominięcia rangi i roli grupy odbiorczej. Proponuję - siłą rzeczy bardzo skrótowe - rozpatrzenie tej sztuki w perspektywie realizmu afektywnego ${ }^{20}$.

Realizm afektywny nie jest wyłącznie doświadczaniem i rejestrowaniem rzeczywistości, ale również jej testowaniem, prowokowaniem i wywoływaniem. Funkcją laboratorium artystycznego bywa generowanie nowych przeżyć, znaczeń i technik. Taka sztuka jest ciągłym procesem, praktykowaniem kulturowej „czasownikowości” (Nycz) lub „czynnościowości” (Kulik). Chodzi nie tylko o szukanie form werbalizacji doświadczeń, ale też o proponowanie nowych formuł doświadczania realiów, ustanawiania relacji między twórcą,

alizmu afektywnego, "Didaskalia" 2015 nr 127: Realizm afektywny. Bardzo wstepner w: Projekt na daleką metę. Prace ofiarowane Ryszardowi Nyczowi, red. Z. Łapiński, A. Nasiłowska, Wydawnictwo IBL PAN, Warszawa 2016. Por. F. Jameson The Antinomies of Realism, Verso, New York-London 2013; L. Berlant Cruel Optimism, Duke University Press, Durham-London 2011; K. Bojarska Patos codzienności (kobieta-biografia-fotografia), w: Kultura afektu, afekty w kulturze. Humanistyka po zwrocie afektywnym, red. R. Nycz, A. Łebkowska, A. Dauksza, Wydawnictwo IBL PAN, Warszawa 2015. 
dziełem i odbiorcą, poruszania zastanym układem odniesień. Siłą rzeczy pod wpływem inwencyjnie oddziałującego realizmu afektywnego zmienia się również perspektywa i wrażliwość odbiorcza oraz ocena dotychczasowego kanonu reprezentacji. Artystyczne „czynnościowanie” wiąże się więc z podawaniem w wątpliwość obowiązujących standardów przedstawiania, znoszeniem przyzwyczajeń percepcyjnych, ustanawianiem odmiennych hierarchii opisu i oglądu.

Działania Rajkowskiej prawie zawsze są efektem pracy w konkretnym miejscu, z własnym i cudzymi ciałami, i nieodmiennie sprowadzają się do bycia, rejestrowania, czujności wobec tego, co się wydarza. W odniesieniu do tych wrażeń konstruowana jest rama, „w której inni mogą się odnaleźć”21. Chodzi o uważność na otoczenie i własne, często podprogowe reakcje, immersyjne zanurzenie w realiach. Rajkowska określa ten mechanizm jako:

próbę znalezienia jakiejś równowagi w miotaniu się między byciem a działaniem, opartą na umiejętności obserwacji momentów bierności, niemocy i poddania się. A nie ciągłe transformowanie, planowanie, szlifowanie rzemiosła czy języka, gdy świat mija cię jak stado meteorytów, gdy nie uczestniczysz w niczym, niczego nie przeżywasz. [...] Nie jesteś w stanie odczuwać tego w pełni, poddać się temu. Ten element bierności, bycia swego rodzaju odbiornikiem, sejsmografem, jest rzeczą podstawową. Żeby się jednak poddać, żeby spróbować przetestować na sobie tę rzeczywistość, żeby ona cię przerobiła, przejechała jak czołg. ${ }^{22}$

Apologia immersyjnej bierności nie jest jednak formą eskapizmu, przeciwnie - u Rajkowskiej z pełnej pasji pasywności rodzi się zaangażowanie. Nie trzeba chyba przypominać, że dla Adorna właśnie w tym punkcie otwiera się możliwość zbliżenia do zapośredniczonej w dziele realności, gdy jednostka „w pozbawionej lęku pasywności powierza się" temu epistemologicznemu doświadczeniu ${ }^{23}$. Dla Rajkowskiej zaangażowanie osadzone jest w intymności i afektywności, co dzięki praktykom artystycznym zyskuje rangę polityczną - zgodnie z zasadą, że „prawdziwą polityką jest polityka dnia codziennego".

21 Sztuka publicznej możliwości, s. 249.

Rzeczywistość milionpostaciowa. Rozmowa z Magdą Raczyńska, http://www.rajkowska.com/pl/ teksty/44, (14.06.16).

23 T.W. Adorno Critical Models: Interventions and Catchwords, trans. by H.W. Pickford, Columbia University Press, New York 1998. 
Te artystyczne, a zarazem ,intymne techniki docierania do sensu" chciałabym właśnie określać mianem realizmu afektywnego.

Realizm afektywny rozumiem jako: (1) metodę rejestrowania - nie tyle opierającej się przedstawieniu „rzeczywistości”, ile raczej napięć między "zewnętrzem" i „wnętrzem”, własnymi odczuciami, reakcjami, afektywnymi poruszeniami, nieustannie powstającymi w jednostce w konsekwencji konfrontowania się z różnymi przejawami owej „rzeczywistości”; (2) formę komunikacji, wymiany, pole relacji między jednostką i jej otoczeniem oraz istniejącymi formami estetycznej ekspresji; (3) sposób dokumentowania, archiwizowania, utrwalania sprofilowanego obrazu realiów; (4) możliwy do aktualizowania w akcie odbioru imperatyw, pakt czy propozycję odniesienia się do cudzej, prezentowanej lub odgrywanej struktury odczuwania, doświadczania i rozumienia realiów.

Jaka jest stawka podobnych praktyk? Rajkowska stwierdza, że chodzi o „zerowanie"24, wytwarzanie momentów niewygody, niezręczności ${ }^{25}$, gdy społeczne rytuały okazują się nieadekwatne do sprowokowanej sytuacji. Można dopowiedzieć, że ważne jest wahanie i niewiedza, które zmuszają odbiorców do zintensyfikowania uważności. Wybierane przez Rajkowską przestrzenie stają się miejscami wspólnymi, polami intensywności, ramami, gdzie przez różne, niekiedy niechętne lub wrogie konfrontacje, dochodzi do elementarnego zawiązania relacji. Laboratoryjna metoda aranżowania pewnych warunków, by możliwe było obserwowanie powstających i zagęszczających się sieciowych powiązań, wydaje się z tej perspektywy wizualizowaniem, inscenizowaniem czy wprost materializowaniem metafory różnicy. Zmieniają się obiekty, nośniki czy nosiciele - jak palma, minaret, dotleniaczowy staw czy wulkan Umea - lecz zasada jest podobna: eksponowanie „dziwnej krawędzi między rzeczywistością a rzeczywistością lekko konstruowaną, lekko reżyserowaną, która pozostaje odczuwalna"26, szokowe dotykanie miejsc wrażliwych, wyszukiwanie „szczelin i porów”, przez które "można byłoby się prześlizgnąć i rozsadzić od środka" pamięć, wyobrażenia czy utarte schematy zachowania ${ }^{27}$. Co jednak istotne, w realizm afektywny

24 Dotleniacz, w: Rajkowska. Przewodnik Krytyki Politycznej, s. 93.

25 Jestem człowiekiem, który się mało dziwi. Z Joanną Rajkowską rozmawiają Paweł Mikołaj Krzaczkowski i Piotr Machłajewski, w: Rajkowska. Przewodnik Krytyki Politycznej, s. 204. 
Rajkowskiej - tj. rejestrowanie i demonstrowanie własnych i cudzych poruszeń - immanentnie wpisana jest słabość, nie ma tu mowy o scenariuszach pozytywnych, o projektowanych zmianach społecznych czy o trwałym przekroczeniu podziałów. Jeśli Witold Gombrowicz deklarował niegdyś, że jest jak aspiryna, która „usuwa nadmierny skurcz"28, to Rajkowska przeciwnie - zakłada procesualne, także przyszłościowe trwanie swojej sztuki i stwierdza wprost: „żadnej terapii, jestem od wywoływania gorączki, tego stanu, w którym organizm może bronić się sam" ${ }^{\text {"29 }}$. Być może w tej taktyce zawiera się także formuła nowego realizmu?

\section{Abstract}

\section{Agnieszka Dauksza}

JAGIELLONIAN UNIVERSITY (CRACOW)

Artistic Laboratory - Affective Realism: Joanna Rajkowska's Practice

In this article Dauksza explores realism as an operational concept that not only helps to describe a given work's intratextual/visual reality in an effective way, but that also allows to describe the relationship artist-work-viewer-reality, the tensions that indicate the direction of the reception process, the artist's/viewer's dependence on the work's materiality and the context of the cognitive situation. Dauksza proposes the term 'affective realism,' which she uses to analyse Joanna Rajkowska's artistic practices. According to Dauksza, Rajkowska uses the laboratory method of arranging the exchange field in order to observe the emerging and thickening network of connections, in order to let tensions materialize and to stage the metaphor of difference.

\section{Keywords}

affect, realism, laboratory, Joanna Rajkowska, Theodor Adorno

W. Gombrowicz Dziennik 1953-1969, Wydawnictwo Literackie, Kraków 2013, S. 145. 